\title{
Possible Subterranean Entrance of Ocean Water into the Caño Tiburones Area in Northern Puerto Rico ${ }^{1}$
}

\author{
Raúl Pérez Escolar ${ }^{2}$
}

\begin{abstract}
Data relative to the salinity of representative drainage water samples from the Caño Tiburones area, Puerto Rico, are presented in this paper. Practically all of these water samples contained large amounts of salts, which makes the water of Caño Tiburones undesirable for irrigation except in prolonged dry periods. The ratio of $\mathrm{Na}$ to $\mathrm{Mg}$ of 13 out of 15 water samples was similar to that of ocean water, namely, 8.34. This could be due either to the fact that the area was affected long ago by ocean water and the present pumping system has not been able to leach out a good part of the salts deposited; or to the possibility that ocean water is at present entering into the Cano Tiburones area through underground tectonic fractures or channels.
\end{abstract}

\section{INTRODUCTION}

The Caño Tiburones area is a narrow, rather long depression about $15 \mathrm{~km}$ long by $1.5 \mathrm{~km}$ wide, approximately 5500 acres. It is located on the northern coast of Puerto Rico between the municipalities of Arecibo and Barceloneta. It extends from the mouth of Arecibo river, one of the largest of the Island, to a short distance west of the Manati river. The area is separated from the sea, about two kilometers to the north, by gently rolling tertiary limestone hills and coastal plains. Its soils range from organic soils near sea level, with approximately 3700 acres, to mineral soils, about two meters above sea level along the border of the sea, comprising 1800 acres.

According to Roberts ${ }^{3}$, the agricultural development of the Caño Tiburones area began in 1907 with partial reclamation of a few tracts for sugarcane production. At present, only 380 acres of land in Finca Matos are planted to sugarcane. The rest has been abandoned.

In 1949 the Land Authority of Puerto Rico started to reclaim this large area for agricultural use. A $60 \mathrm{ft}$-wide, $20 \mathrm{ft}$-deep principal canal, $15.3 \mathrm{~km}$ long, which slopes from east to west, was built to take care of the water of the area itself and of the water coming from diversion canals which border the area on the south, east, and northeast. The principal drainage canal is supplemented by another larger canal in the central northern part of the area. There are around 132 supplementary canals.

'Manuscript submitted to Editorial Board April 15, 1977.

${ }^{2}$ Soil Scientist, Agricultural Experiment Station, Mayagëz Campus, University of Puerto Rico, Río Piedras, P.R.

${ }^{3}$ Roberts, R. C., Soil Survey of P.R., USDA Bur. Plant Ind., and Univ. P.R. 1942. 
These drainage canals are joined by submains every 200 to $300 \mathrm{~m}$ apart flowing in a north to south and south to north direction. These submain canals collect drainage waters from field laterals. Automatic tidal gates operating both on the northeastern and northwestern corners of the area prevent entry of sea water. A pumping station installed in the northwestern corner consists of 4 turbines with a capacity of about $300,000 \mathrm{gal} / \mathrm{min}$ removing an average of 260 acre-ft daily.

A preliminary study on the salt content of the area has been made by the Soils Department of the Agricultural Experiment Station, Univeristy of Puerto Rico. It was the purpose of the present study to determine the salts and salt species present in the drainage water of different sites throughout the Caño Tiburones in an attempt to determine their possible origin.

\section{MATERIALS AND METHODS}

Water samples from representative places throughout the Caño Tiburones area were taken. The sites included several points in the main drainage canals, laterals, and the springs known locally as "cáncoras" which occur in low spots. (Some of these "cáncoras" have fresh water and others a high salt content.) Chemical measurements conducted on the water samples included electrical conductivity, Ca, $\mathrm{Mg}, \mathrm{Na}, \mathrm{K}, \mathrm{Cl}$, and $\mathrm{SO}_{4}$. Electrical conductivity was measured using a standard Solu-bridge ${ }^{4}$. $\mathrm{Ca}, \mathrm{Mg}, \mathrm{Na}$, and $\mathrm{K}$ were determined in the flame photometer. Chlorides were determined by the silver nitrate method of Mohr ${ }^{5}$, whereas sulfates were determined by precipitation with $\mathrm{BaCl}_{2}$. The total salt content present in an acre-in of water was calculated on the basis of $\mathrm{NaCl}$ equivalent by multiplying the electrical conductivity by 10 and this by 58.5, the milligram-equivalent weight of $\mathrm{NaCl}$. The result yielded $\mathrm{mg} \mathrm{NaCl} / \mathrm{l}$, which was further converted to lbs NaCl/26,781 gal (an acre-in of water).

\section{RESULTS AND DISCUSSION}

The first column in table 1 shows the electrical conductivity of the water samples studied. The values vary from $0.48 \mathrm{mmhos} / \mathrm{cm}$ to 42.0 $\mathrm{mmhos} / \mathrm{cm}$. It is clearly seen that most of this water has an extremely high salt content, making most of it undesirable for supplementary irrigation purposes except, of course, in prolonged dry periods. Even the water with a relatively low conductivity value would be recommended only for soils of good internal drainage.

"Trade names are used in this publication solely for the purpose of providing specific information. Mention of a trade name does not constitute a guarantee or warranty of equipment or materials by the Agricultural Experiment Station of the University of Puerto Rico or an endorsement over other equipment or materials not mentioned.

${ }^{5}$ Mohr, F., Volumetric determination of chloride ion. Quantitative Analysis, 3rd ed. pp 70-2, 1951 . 
TABLE 1. - Salt content and species, and sodium to magnesium ratio of drainage waters of the Caño Tiburones ${ }^{5}$

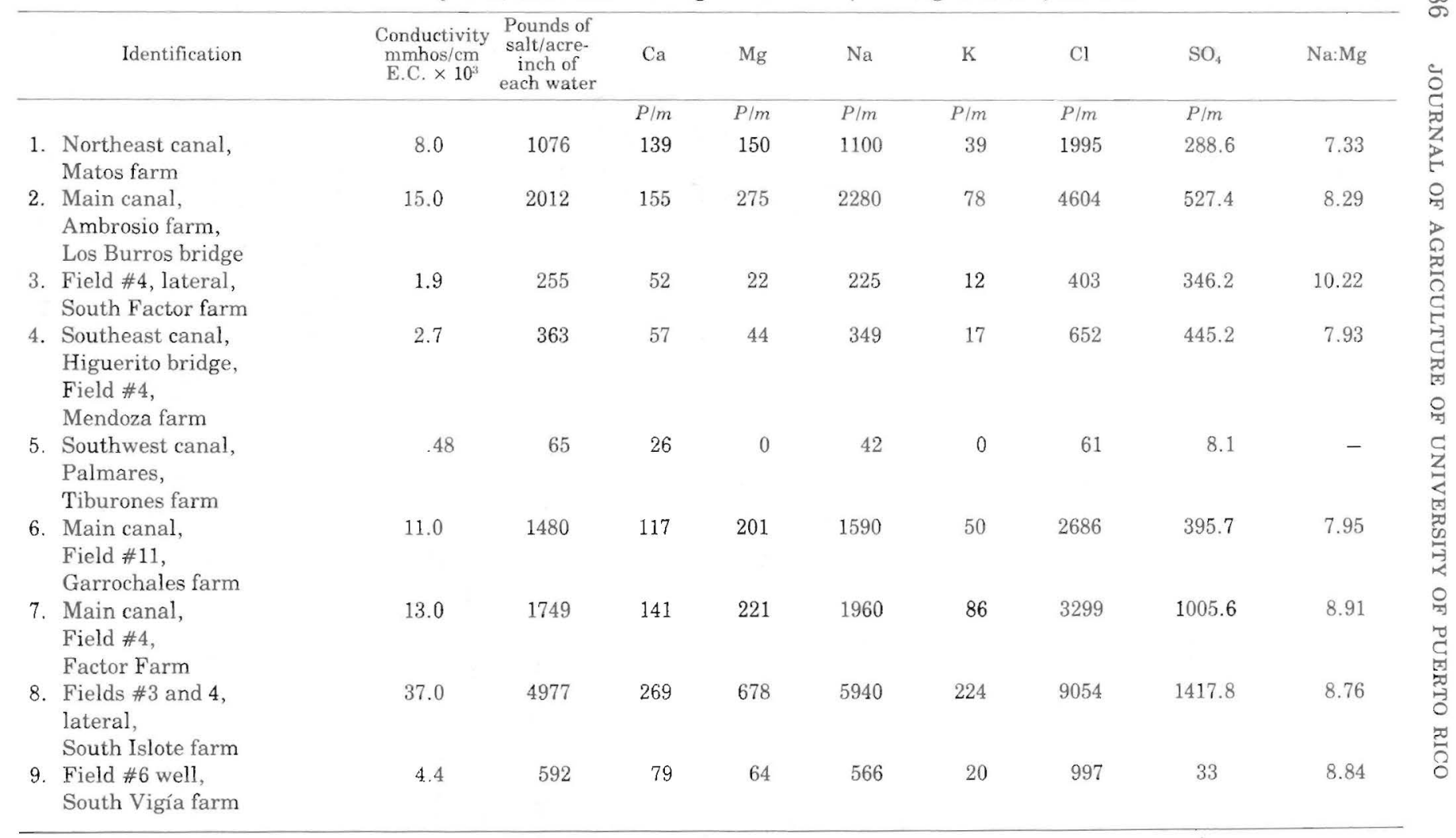


TABLE $1-$ Continued

\begin{tabular}{|c|c|c|c|c|c|c|c|c|c|c|}
\hline 10. & $\begin{array}{l}\text { Main canal origin, } \\
\text { Field \#8, } \\
\text { Mendoza farm }\end{array}$ & 12.0 & 1614 & 234 & 212 & 1710 & 35 & 2954 & 477.9 & 8.06 \\
\hline 11. & $\begin{array}{l}\text { Southeast canal bridge, } \\
\text { Field \#13, } \\
\text { Palmas Altas }\end{array}$ & 23.0 & 3094 & 164 & 466 & 4110 & 149 & 5939 & 675.9 & 8.74 \\
\hline 12. & $\begin{array}{l}\text { North canal, } \\
\text { Los Negros bridge, } \\
\text { Field \#12, } \\
\text { Matos farm }\end{array}$ & 7.2 & 968 & 112 & 114 & 1010 & 27 & 1749 & 618.3 & 8.85 \\
\hline 13. & $\begin{array}{l}\text { Main canal, } \\
\text { Field \#5, } \\
\text { Garrochales farm }\end{array}$ & 12.1 & 1627 & 164 & 199 & 1730 & 50 & 2962 & 923.1 & 8.69 \\
\hline 14. & $\begin{array}{l}\text { North canal, } \\
\text { Field \#1, } \\
\text { Factor farm }\end{array}$ & 42.0 & 5650 & 309 & 868 & 7110 & 252 & 11632 & 1500 & 8.19 \\
\hline 15. & $\begin{array}{l}\text { Southeast canal } \\
\text { bridge, } \\
\text { Administrator's house, } \\
\text { Garrochales farm }\end{array}$ & 4.8 & 646 & 24 & 0 & 42 & 10 & 58 & 247.2 & - \\
\hline
\end{tabular}

5 The author is grateful to Mr. Eduardo J. Brenes, former Associate Soil Scientist, for suggesting the use of $\mathrm{Na}$ to $\mathrm{Mg}$ ratio as an index of comparing drainage water samples with ocean water. 
The bases and anions shown in the table are correspondingly high. The presence of high Ca content is explained probably by the closeness of the limestone hills to the southern part of the area, but the only apparent explanation for the rather high $\mathrm{Na}$ and $\mathrm{Mg}$ content is the fact that geologically this area was under marine influence in Pleistocene and early Halocene periods. It is interesting that 13 out of the 15 water samples have a $\mathrm{Na}$ to $\mathrm{Mg}$ ratio in the neighborhood of that of ocean water, namely, 8.34. The other two samples show a $\mathrm{Na}$ to $\mathrm{Cl}$ ratio similar to that of ocean water. Two possibilities might explain this. It could be that even with the present pumping system of the area a good part of the salts which were deposited long ago are still in the soil profile, or that ocean water enters into the Cano Tiburones area through underground geologic fractures or channels. If the latter is the cause, it is likely that in many areas of the Caño Tiburones salinity may increase with time.

\section{RESUMEN}

En este trabajo se informan datos relativos a la salinidad de muestras representativas de aguas de drenaje del Caño Tiburones en Puerto Rico. Casi todas las muestras arrojan un alto contenido de sales, lo que hace las aguas indeseables para regar, excepto en casos de sequía prolongada. La razón de sodio a magnesio en 13 de las 15 muestras es similar a la del agua del mar; a saber, 8.34. Esto puede deberse a que el área estuvo bajo la influencia del mar en épocas pasadas y que el presente sistema de bombeo ha sido ineficaz para remover gran parte de estas sales; o quizás, a que el agua del mar esté entrando al Caño Tiburones por alguna fractura geológica o canal subterráneo. 